\title{
Haematological analyses in rainbow trout Oncorhynchus mykiss affected by viral haemorrhagic septicaemia (VHS)
}

\author{
J. ̌̌Rehulka* \\ Department of Zoology, Silesian Museum, Tyršova 1, 74646 Opava, Czech Republic
}

\begin{abstract}
Rainbow trout Oncorhynchus mykiss weighing $87 \pm 15 \mathrm{~g}$ (mean $\pm \mathrm{SD}$ ) were infected with viral haemorrhagic septicaemia virus (VHSV) and the haematological and biochemical profiles of peripheral blood examined. Depending on the clinical signs and gross pathology, the fish were divided into 2 groups: Group A included fish in the acute stage, Group B comprised fish in the chronic stage. Red blood cells were subjected to 6 haematological tests and blood plasma to 14 biochemical tests, which provided findings on changed substrate concentrations and enzyme activities. Diseased fish, compared to healthy fish, had a significantly lower red blood cell count, and lower haematocrit and haemoglobin levels. As for the biochemical parameters, the fish had less total protein, creatinine, glucose, triacylglycerol, inorganic phosphate, total calcium and sodium, and more blood urea, nitrogen and potassium. Uric acid levels remained unchanged. Increases were recorded in the catalytic concentration of alanine aminotransferase, aspartate aminotransferase and lactate dehydrogenase. A decrease was recorded in the catalytic concentration of alkaline phosphatase. Fish with VHS in the chronic stage, compared with healthy fish, were in worse condition, with a significantly reduced Fulton coefficient and Clark coefficient, and a higher hepatosomatic index and visceral somatic index.
\end{abstract}

KEY WORDS: Rainbow trout - Viral haemorrhagic septicaemia - VHS · Haematological indices · Biochemical indices $\cdot$ Condition indices

\section{INTRODUCTION}

Viral haemorrhagic septicaemia (VHS) is among the most major diseases in salmonid aquaculture. Its occurrence is responsible for 80 to $100 \%$ losses, especially in fry and other marketable fish during the first year of their life. The causative agent of the disease was first isolated in cell cultures derived from the ovaries of juvenile trout (Jensen 1963) and the rhabdoviral oetiology subsequently demonstrated by electron microscopy (Zwillenberg et al. 1965). The most susceptible fish species are generally salmonids, especially rainbow trout Oncorhynchus mykiss, but the disease may also affect non-salmonids such as pike Esox lucius (Meier \& Pfister 1981) or turbot Scophthalmus maximus (Schlotfeldt et al. 1991).
To achieve good growth of rainbow trout in aquaculture, fish must be healthy, well-fed and the water must be of the required quality. Methods of preventive examination of fish health in aquaculture include haematological and biochemical analyses of blood. Early detection of changes in red blood cell parameters, and the indicators of nitrogen, carbohydrate, lipid and mineral metabolism, and also fluctuations in the catalytic concentrations of enzymes, require other diagnostic methods to be used in order to identify the cause of disorders in fish. Other studies have previously drawn attention to the importance of enhancing the knowledge of the clinical haematology and biochemistry of salmonids affected by infectious bacteria (Hunn 1964, Post 1966, Mulcahy 1969,1971, Cardwell \& Smith 1971, Foda 1973, Racicot et al. 1975, Shieh 1978, Harbell et al. 
1979, Barham et al. 1980, Waagbø et al. 1988, Řehulka 2002) or viruses, including infectious haematopoietic necrosis (Amend \& Smith 1975) and VHS (Lehmann \& Stürenberg 1975, Hoffmann et al. 1979, Amlacher et al. 1980, Hoffmann 1980, Hille 1983, Pöllnitz et al. 1994). These studies focused on the pathological morphology of the blood cells. Studying the development of organ lesions in rainbow trout with experimentally induced VHS, Hoffmann et al. (1979) found that many immature blood cells were diagnosed in peripheral blood during the later stages of disease. The importance of these processes were discussed, with special reference to the development of haemorrhagic diathesis, as well as to the defence system of fish. Amlacher et al. (1980), conducting haematological investigations in $1 \mathrm{yr}$ old farmed rainbow trout naturally infected with VHS virus (VHSV), observed diverse stages of erythrocytic degeneration, amitoses of the erythrocytes, and a 5-fold increase in lymphocyte numbers in the peripheral blood of the fish. The ratio of immature to mature erythrocytes was 1:11 in diseased trout and 1:5 in the healthy control group. This suggests that the haematopoietic activity of the auterior kidney in diseased trout may be reduced to up to half that of the normal rate as a result of viral infection. Pölnitz et al. (1994) stated that within anaemic fish there is a remarkable increase in the number of monocytes, despite a reduced number of leucocytes in the peripheral blood; in the head kidney there is an increase of erythrocytes by 4 -fold and of erythroblasts by 3 -fold. In the biochemical indices, VHS caused low blood sugar, total protein, albumin, globulin and bilirubin levels (Deufel 1959, Haider 1969, ReichenbachKlinke 1970, Ahne et al. 1976).

The purpose of this study was to describe the changes in the blood of juvenile rainbow trout during the occurrence of a natural infection of VHSV.

\section{MATERIALS AND METHODS}

Fish. The disease outbreak occurred in May 1999 on a trout farm, in 1 of 20 tanks. In all, 1500 fish were kept in flow-through round metallic tanks, $6 \mathrm{~m}$ diameter and $4 \mathrm{~m}$ depth, and maintained at a water temperature of $5^{\circ} \mathrm{C}$. The body weight of the fish was $87 \pm 15 \mathrm{~g}$ (mean $\pm \mathrm{SD}$ ) and standard length was $179 \pm 12 \mathrm{~mm}$. As later discovered, the infection had been introduced by vertical transmission from one of the parent fish, from which VHSV was isolated. Depending on clinical signs and gross pathology, diseased fish were divided into 2 groups. Group A included fish at the acute stage (dark colouration, unilateral exophthalmus, pale gills and haemorrhaging of eyes, skin, viscera and base of pectoral fins). Group B comprised fish at the chronic stage (severe pale gills, intensive darkening and exophthal- mus). A blood sample was taken and the fish was subjected to pathologico-anatomical analysis. Its organs were collected for histological and virological examination.

Sampling procedure for histopathology. Samples from 20 fish were fixed in a $10 \%$ neutral-buffered formalin solution. Histological sections were stained as follows: haematoxylin-eosin, Gram, PAS method (periodic acid Schiff's reagent), Masson green trichrome, Gömöri's method, and Van Gieson. Perl's staining method was used for the detection of iron and Lugol's solution (Stein) was used to identify bile pigments.

Virological examination. Samples of spleen and heart were used for virological examination. In the ELISA examination of the tissue culture, a value of 1.473 was obtained in the RTG cells and 1.345 in the FHM cells. Electron microscopy confirmed the presence of rhabdovirus particles. Virological examination was performed in the National Reference Laboratory for Viral Fish Diseases.

Preparation of blood samples. Blood was sampled from fish showing clinical signs of disease: 10 fish from Group A and 10 fish from Group $B_{;}$and from 10 healthy fish from another tank. The fish were anaesthetised with Menocaine/3-ethoxycarbonylfenyl/ ammonium natrium hydrogensulfuricum at a concentration of $0.1 \mathrm{~g} \mathrm{l}^{-1}$, and the samples were then taken by puncturing the caudal vein between 07:00 and 11:00 h. EDTA and sodium heparin (5000 international units [IU] in a $1 \mathrm{ml}$ injection) were used as anticoagulants, the former being used for the haematological examination and the latter for biochemical analyses of blood plasma. Haematocrit $(\mathrm{Ht})$ values were determined immediately after sampling. The red blood cell count $(\mathrm{RBCC})$ and haemoglobin $(\mathrm{Hb})$ values were determined afterwards. Plasma was obtained by centrifuging the blood at $400 \times g$ for $10 \mathrm{~min}$ at $4^{\circ} \mathrm{C}$ and then removing it with a plastic syringe. All determinations were performed within $24 \mathrm{~h}$ of sample collection.

Haematology. The RBCc $\left(\mathrm{Tl}^{-1}\right)$ was determined using the Bürker haemocytometer; the Hayem solution was applied and the erythrocytes were counted in $2 \times$ 20 rectangles. Ht was determined in heparinised microhaematocrit capillaries in duplicate, using a microhaematocrit centrifuge $(15300 \times g$ for $3 \mathrm{~min})$. $\mathrm{Hb}$ (in $\mathrm{g}^{-1}$ ) was determined by the standard cyanohaemoglobin method. Derived blood indices of mean corpuscular volume ( $\mathrm{MCV}$, in $\mathrm{fl})$, mean corpuscular haemoglobin $(\mathrm{MCH}$, in $\mathrm{pg})$, and mean corpuscular $\mathrm{Hb}$ concentration (MCHC) were calculated from haematological figures.

Blood chemistry. A Hitachi 704C analytical instrument was used for the following determinations involving the Cfas calibrator for automatic systems (Roche). Kits produced by PLIVA-Lachema, a.s. Brno, Czech 
Republic, and DIALAB Wien, Austria, and Prague, Czech Republic, were used for the determination of all indices. For controls, BIO-LA-TEST ${ }^{\circledR}$ LYONORM $^{\circ}$ HUMAN N Cat. No. 10003204, 1301566, DIACON N Cat. No. D 98481 and DIALAB Cat. No. 188481 were used. These included: total protein ( $\mathrm{TP}$, in $\mathrm{g} \mathrm{l}^{-1}$ ), blood urea nitrogen (BUN, in mmol $\mathrm{l}^{-1}$ ), uric acid (UA, in

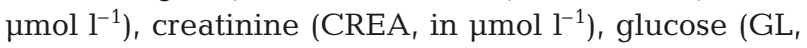
in $\mathrm{mmol} \mathrm{l}^{-1}$ ), triacylglycerol (TGL, in $\mathrm{mmol} \mathrm{l}^{-1}$ ), inorganic phosphate $\left(\mathrm{P}\right.$, in mmol $\left.\mathrm{l}^{-1}\right)$, total calcium $(\mathrm{Ca}$, in

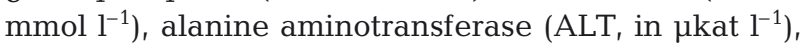
aspartate aminotransferase (AST, in $\mu \mathrm{kat}^{-1}$ ), alkaline phosphatase (ALP, in $\mu \mathrm{kat}^{-1}$ ), and lactate dehydrogenase (LD, in $\left.\mu \mathrm{kat}^{-1}\right)$. The sodium cation $\left(\mathrm{Na}^{+}\right.$, in $\mathrm{mmol}$ $\mathrm{l}^{-1}$ ) and potassium cation $\left(\mathrm{K}^{+}\right.$, in $\left.\mathrm{mmol} \mathrm{l}^{-1}\right)$ were determined by flame-emission photometry.

Assessment of the biometry organs. For evaluation of the overall condition of the fish, the Fulton coefficient $(F C)$ (body weight in $g \times 100 /$ standard length $^{3}$, in $\mathrm{cm})$, Clark coefficient (CC) (body weight without viscera in $\mathrm{g} \times 100 /$ standard length $^{3}$, in $\mathrm{cm}$ ), Hepatosomatic Index 1 (HI 1) (liver weight as a \% of body weight), Hepatosomatic Index 2 (HI 2) (liver weight as a $\%$ of body weight without viscera) and Viscera Somatic Index (VSI) (viscera weight as a \% of body weight) were determined. The total weight of the fish and the weight of the fish without viscera were recorded to an accuracy of $1 \mathrm{~g}$, and the weight of the liver was determined to an accuracy of $0.01 \mathrm{~g}$.

Statistical analysis. Data from healthy and diseased fish were compared using the $F$-test and $t$-test. All calculations were made using the UNISTAT ${ }^{\circledR}$ (1995) statistical package for MS Windows ${ }^{\mathrm{TM}}$. All the procedures used are described in the User Guide.

\section{RESULTS}

\section{Clinical signs and gross pathology and histopathology}

The fish showed signs of lethargy, stayed at the periphery of the tank and showed different degrees of pale gills. Some had a dark body colour and a unilateral or bilateral exophthalmus, with either absence or presence of haemorrhage in eyes. The colour of their liver ranged from normal, to wine-red, up to yellow, and often signalled focal lack of blood perfusion. Haemorrhagic diathesis manifested itself on the liver, pyloric caeca, fatty tissue and the wall of the swimbladder. Stripe-like or petechial haemorrhage also occurred in the muscle. The anterior kidney was pale, the gut was swollen at the end, the anus was reddened and slightly prolapsed. The ascites bud was either absent, clear, or had an addition of red blood cells.
The kidney showed a considerable reduction of haemopoietic tissue. The glomeruli were enlarged with dilated capillary loops and with the presence of inflammatory infiltrate. The walls of the basal membranes were thickened and there were signs of concentration of fine-grained and fibrous protein material in the Bowman's capsule. In addition to the preserved acinar structure, there were focal necroses, with or without a light to severe occurrence of diffuse smallvariability fatty vacuoles in the liver as a sign of prolonged course of disease. A discrete inflammatory response often occurred in the portal fields. The blood capillaries showed signs of being in a septic state with necrotic debris, with prevalence of immature red and white blood cells. These findings corresponded to acute hepatitis. The heart showed severe acute myocarditis with focal regressive changes of the fibres.

\section{Haematology and clinical chemistry}

The haematological and biochemical profiles of the diseased fish are documented in Tables $1 \& 2$. Changes in the red blood component with manifestations of reduced $\mathrm{RBCC}_{1} \mathrm{Ht}$ and $\mathrm{Hb}$ values (more significant in Group B) are the key feature of the clinical picture of the fish in both groups. Except for RBCc, all the values of the fish in Group A were below our laboratory's reference range for healthy fish values (RBCC: 0.77 to $1.42 ; \mathrm{Ht}$ : 0.304 to 0.502 ; Hb: 54 to 92.6) (Řehulka \& Minařík 2003), and in comparison with healthy fish they were highly variable (RBCc: 0.18 to 1.42 ; Ht: 0.06 to $0.417 ; \mathrm{Hb}: 13.7$ to 82.6). In comparison with healthy fish, MCV values in this group signalled that diseased fish were prone to normochromic microcytic anaemia (221 to 381 vs 262 to 407 ) and these values were at the lower limit of the reference values (282 to 469). The red blood component in the fish in Group B offered a much more dramatic picture, showing an escalated severe hypochromic normocytic anaemia. The RBCc (0.07 to 0.4 vs 0.99 to 1.47 ), Ht (0.04 to 0.145 vs 0.417 to 0.556 ) and Hb values (5 to 21.9 vs 87.7 to 98.7 ) were below those of the healthy fish.

Within the spectrum of biochemical parameters, the fish in Group B showed a greater number of differences between the diseased and healthy fish. Regarding nitrogen metabolism, there was a marked hypoproteinaemia (10 to 17 vs 40 to 50 ), an increase in BUN ( 0.4 to 0.9 vs 0.4 to 0.6 ) and decrease in CREA (12 to 20 vs 43 to 65 ) in the diseased fish. The most marked change in carbohydrate metabolism was the $50 \%$ reduction of GL ( 0.6 to 7.2 vs 4.2 to 11.7 ), and in lipid metabolism it was the TGL level, which was 4 times lower than in healthy fish (0.4 to 4.2 vs 6.5 to 16.7). The levels of osteotrophic elements $\mathrm{P}$ and $\mathrm{Ca}$, as well as the level of the $\mathrm{Na}^{+}$cation, were also lower (P: 2.52 to 4.34 vs 4.49 to 5.86 ; Ca: 1.82 to 
Table 1. Oncorhynchus mykiss. Comparison of the haematological and biochemical parameters of diseased (viral haemorrhagic septicaemia virus; VHSV) and healthy rainbow trout (Group A, $\mathrm{n}=10$ ). SEM: standard error of the mean; ${ }^{*} \mathrm{p}=0.05 ;{ }^{* *} \mathrm{p}=0.01$. RBCC: red blood cell count; Ht: haematocrit; Hb: haemoglobin; MCV: mean corpuscular volume; MCH: mean corpuscular haemoglobin; MCHC: mean corpuscular haemoglobin concentration; TP: total protein; BUN: blood urea nitrogen; UA: uric acid; CREA: creatinine; GL: glucose; TGL: triacylglycerol; P: inorganic phosphate; Ca: total calcium; $\mathrm{Na}^{+}$: sodium cation; $\mathrm{K}^{+}$: potassium cation;

ALT: alanine aminotransferase; AST: aspartate aminotransferase; ALP: alkaline phosphatase; LD: lactate dehydrogenase

\begin{tabular}{|c|c|c|c|c|c|c|c|c|c|c|}
\hline \multirow[t]{2}{*}{ Indices } & \multicolumn{3}{|c|}{ Diseased fish } & \multicolumn{3}{|c|}{ Healthy fish } & \multicolumn{2}{|c|}{$F$-test } & \multicolumn{2}{|c|}{$t$-test } \\
\hline & Mean & $\mathrm{SD}$ & SEM & Mean & $\mathrm{SD}$ & SEM & $F$-value & $\mathrm{p}$ & $t$-value & $\mathrm{p}$ \\
\hline $\mathrm{RBCc} \mathrm{T}^{-1}$ & 0.82 & 0.497 & 0.157 & 1.19 & 0.189 & 0.06 & $6.934^{* *}$ & 0.004 & $-2.243^{*}$ & 0.045 \\
\hline $\mathrm{Ht}$ & 0.246 & 0.159 & 0.05 & 0.422 & 0.072 & 0.023 & $4.883^{*}$ & 0.014 & $-3.186^{* *}$ & 0.008 \\
\hline $\mathrm{Hb} \mathrm{g} \mathrm{l}^{-1}$ & 48.1 & 27.3 & 8.63 & 71.6 & 9.86 & 3.12 & $7.659^{* *}$ & 0.003 & $-2.56^{*}$ & 0.026 \\
\hline MCV fl & 291 & 50 & 15.8 & 357 & 49.2 & 15.6 & 1.034 & 0.48 & $-2.98^{* *}$ & 0.008 \\
\hline $\mathrm{MCH} p g$ & 62 & 7.8 & 2.5 & 61 & 8 & 2.5 & 1.048 & 0.473 & 0.368 & 0.717 \\
\hline $\mathrm{MCHC}$ & 0.219 & 0.046 & 0.014 & 0.171 & 0.01 & 0.003 & $22.73^{* *}$ & 0.000 & $3.247^{* *}$ & 0.009 \\
\hline $\mathrm{TP} \mathrm{g} \mathrm{l}^{-1}$ & 31.7 & 14.59 & 4.86 & 43.1 & 7.71 & 2.44 & $3.58^{*}$ & 0.037 & -2.102 & 0.058 \\
\hline $\mathrm{UA} \mu \mathrm{mol} \mathrm{l} \mathrm{l}^{-1}$ & 75.7 & 14.87 & 5.26 & 83.3 & 10.69 & 3.56 & 1.93 & 0.188 & -1.227 & 0.239 \\
\hline $\mathrm{GL} \mathrm{mmol} \mathrm{l}^{-1}$ & 5.07 & 1.51 & 0.534 & 6.04 & 0.451 & 0.16 & $11.192^{* *}$ & 0.002 & -1.732 & 0.12 \\
\hline P mmol l ${ }^{-1}$ & 3.53 & 0.793 & 0.264 & 4.38 & 0.628 & 0.199 & 1.593 & 0.251 & $-2.613^{*}$ & 0.018 \\
\hline Ca mmol l-1 & 2.74 & 0.626 & 0.208 & 3.22 & 0.198 & 0.066 & $10.032^{* *}$ & 0.002 & -2.185 & 0.055 \\
\hline $\mathrm{Na}^{+} \mathrm{mmol} \mathrm{l}^{-1}$ & 155 & 6.764 & 2.255 & 158.9 & 3.348 & 1.059 & $4.081^{*}$ & 0.025 & -1.566 & 0.145 \\
\hline $\mathrm{K}^{+} \mathrm{mmol} \mathrm{l}^{-1}$ & 1.38 & 1.069 & 0.356 & 0.36 & 0.092 & 0.032 & $136.062^{* *}$ & 0.000 & $2.838^{*}$ & 0.022 \\
\hline ALT $\mu$ kat $l^{-1}$ & 0.24 & 0.072 & 0.026 & 0.21 & 0.064 & 0.021 & 1.295 & 0.36 & 1.059 & 0.306 \\
\hline AST $\mu$ kat $l^{-1}$ & 6.46 & 0.923 & 0.349 & 5.25 & 1.033 & 0.344 & 1.254 & 0.402 & $2.444^{*}$ & 0.028 \\
\hline ALP $\mu$ kat $l^{-1}$ & 5.22 & 3.271 & 1.09 & 7.08 & 2.173 & 0.687 & 2.266 & 0.122 & -1.474 & 0.159 \\
\hline LD $\mu$ kat $\mathrm{l}^{-1}$ & 20.59 & 20.067 & 7.095 & 8.34 & 3.018 & 0.954 & $44.205^{* *}$ & 0.000 & 1.711 & 0.129 \\
\hline
\end{tabular}

Table 2. Oncorhynchus mykiss. Comparison of the haematological and biochemical parameters of diseased (viral haemorrhagic septicaemia virus; VHSV) and healthy rainbow trout (Group $B, n=10$ ). SEM: standard error of the mean; ${ }^{*} p=0.05 ;{ }^{* *} p=0.01$; RBCC: red blood cell count; Ht: haematocrit; Hb: haemoglobin; MCV: mean corpuscular volume; MCH: mean corpuscular haemoglobin; MCHC: mean corpuscular haemoglobin concentration; TP: total protein; BUN: blood urea nitrogen; UA: uric acid; CREA: creatinine; GL: glucose; TGL: triacylglycerol; P: inorganic phosphate; Ca: total calcium; $\mathrm{Na}^{+}$: sodium cation; $\mathrm{K}^{+}$: potassium cation;

ALT: alanine aminotransferase; AST: aspartate aminotransferase; ALP: alkaline phosphatase; LD: lactate dehydrogenase

\begin{tabular}{|c|c|c|c|c|c|c|c|c|c|c|}
\hline \multirow[t]{2}{*}{ Indices } & \multicolumn{3}{|c|}{ Diseased fish } & \multicolumn{3}{|c|}{ Healthy fish } & \multicolumn{2}{|c|}{$F$-test } & \multicolumn{2}{|c|}{$t$-test } \\
\hline & Mean & $\mathrm{SD}$ & SEM & Mean & $\mathrm{SD}$ & SEM & $F$-value & $\mathrm{p}$ & $t$-value & $\mathrm{p}$ \\
\hline $\mathrm{RBCC}_{\mathrm{T} \mathrm{l}}^{-1}$ & 0.22 & 0.098 & 0.013 & 1.31 & 0.174 & 0.055 & 3.163 & 0.051 & $-17.21^{* *}$ & 0.000 \\
\hline $\mathrm{Ht}$ & 0.086 & 0.044 & 0.014 & 0.485 & 0.042 & 0.013 & 1.082 & 0.454 & $-20.64^{* *}$ & 0.000 \\
\hline $\mathrm{Hb} \mathrm{g} \mathrm{l^{-1 }}$ & 10.8 & 7.71 & 2.44 & 89.5 & 5.93 & 1.87 & 1.692 & 0.223 & $-25.593^{* *}$ & 0.000 \\
\hline MCV fl & 388 & 93 & 29.4 & 373 & 26 & 8.2 & $12.818^{* *}$ & 0.000 & 0.501 & 0.627 \\
\hline $\mathrm{MCH}$ pg & 46 & 18.9 & 6 & 69 & 7.6 & 2.4 & $6.234^{* *}$ & 0.006 & $-3.537^{* *}$ & 0.004 \\
\hline $\mathrm{MCHC}$ & 0.117 & 0.036 & 0.011 & 0.185 & 0.011 & 0.004 & $10.575^{* *}$ & 0.001 & $-5.688^{* *}$ & 0.000 \\
\hline $\mathrm{TP} \mathrm{g} \mathrm{l}^{-1}$ & 13.9 & 2.15 & 0.72 & 46.2 & 3.19 & 1.06 & 2.211 & 0.141 & $-25.209^{* *}$ & 0.000 \\
\hline BUN mmol $\mathrm{l}^{-1}$ & 0.7 & 0.16 & 0.05 & 0.5 & 0.06 & 0.02 & $6.139^{* *}$ & 0.006 & $3.556^{* *}$ & 0.004 \\
\hline $\mathrm{UA} \mu \mathrm{mol} \mathrm{l}^{-1}$ & 19.4 & 11.54 & 4.08 & 19.7 & 3.86 & 1.46 & $8.932^{*}$ & 0.008 & -0.078 & 0.939 \\
\hline CREA $\mu \mathrm{mol} \mathrm{l}{ }^{-1}$ & 16.2 & 2.35 & 0.74 & 53 & 8.07 & 2.55 & $11.814^{* *}$ & 0.000 & $-13.848^{* *}$ & 0.000 \\
\hline GL mmol $1^{-1}$ & 3.16 & 1.992 & 0.63 & 6.31 & 2.4 & 0.759 & 1.452 & 0.294 & $-3.194^{* *}$ & 0.005 \\
\hline TGL mmol l-1 & 2.42 & 1.109 & 0.351 & 10.63 & 3.726 & 1.178 & $11.278^{* *}$ & 0.001 & $-6.679^{* *}$ & 0.000 \\
\hline P mmol l-1 & 3.21 & 0.582 & 0.194 & 5.16 & 0.482 & 0.152 & 1.456 & 0.293 & $-7.944^{* *}$ & 0.000 \\
\hline Ca mmol l-1 & 2.08 & 0.281 & 0.094 & 3.5 & 0.243 & 0.081 & 1.334 & 0.347 & $-11.457^{* *}$ & 0.000 \\
\hline $\mathrm{Na}^{+} \mathrm{mmol} \mathrm{l}^{-1}$ & 142.5 & 7.138 & 2.257 & 155.8 & 3.49 & 1.104 & $4.183^{*}$ & 0.022 & $-5.294^{* *}$ & 0.000 \\
\hline $\mathrm{K}^{+} \mathrm{mmol} \mathrm{l}^{-1}$ & 4.09 & 0.719 & 0.227 & 2.68 & 1.076 & 0.34 & 2.24 & 0.123 & $3.446^{* *}$ & 0.003 \\
\hline ALT kat $\mathrm{l}^{-1}$ & 1.16 & 0.752 & 0.238 & 0.58 & 0.187 & 0.059 & $16.152^{* *}$ & 0.000 & $2.343^{*}$ & 0.041 \\
\hline AST $\mu$ kat $l^{-1}$ & 20.41 & 10.263 & 3.879 & 11.45 & 2.204 & 0.697 & $21.687^{* *}$ & 0.000 & 2.274 & 0.061 \\
\hline ALP $\mu$ kat $l^{-1}$ & 2.64 & 1.187 & 0.396 & 12.06 & 4.272 & 1.351 & $12.966^{*}$ & 0.001 & $-6.688^{* *}$ & 0.000 \\
\hline LD $\mu$ kat $l^{-1}$ & 178.7 & 97.764 & 32.588 & 21.44 & 8.442 & 2.67 & $134.092^{* *}$ & 0.000 & $4.81^{* *}$ & 0.000 \\
\hline
\end{tabular}



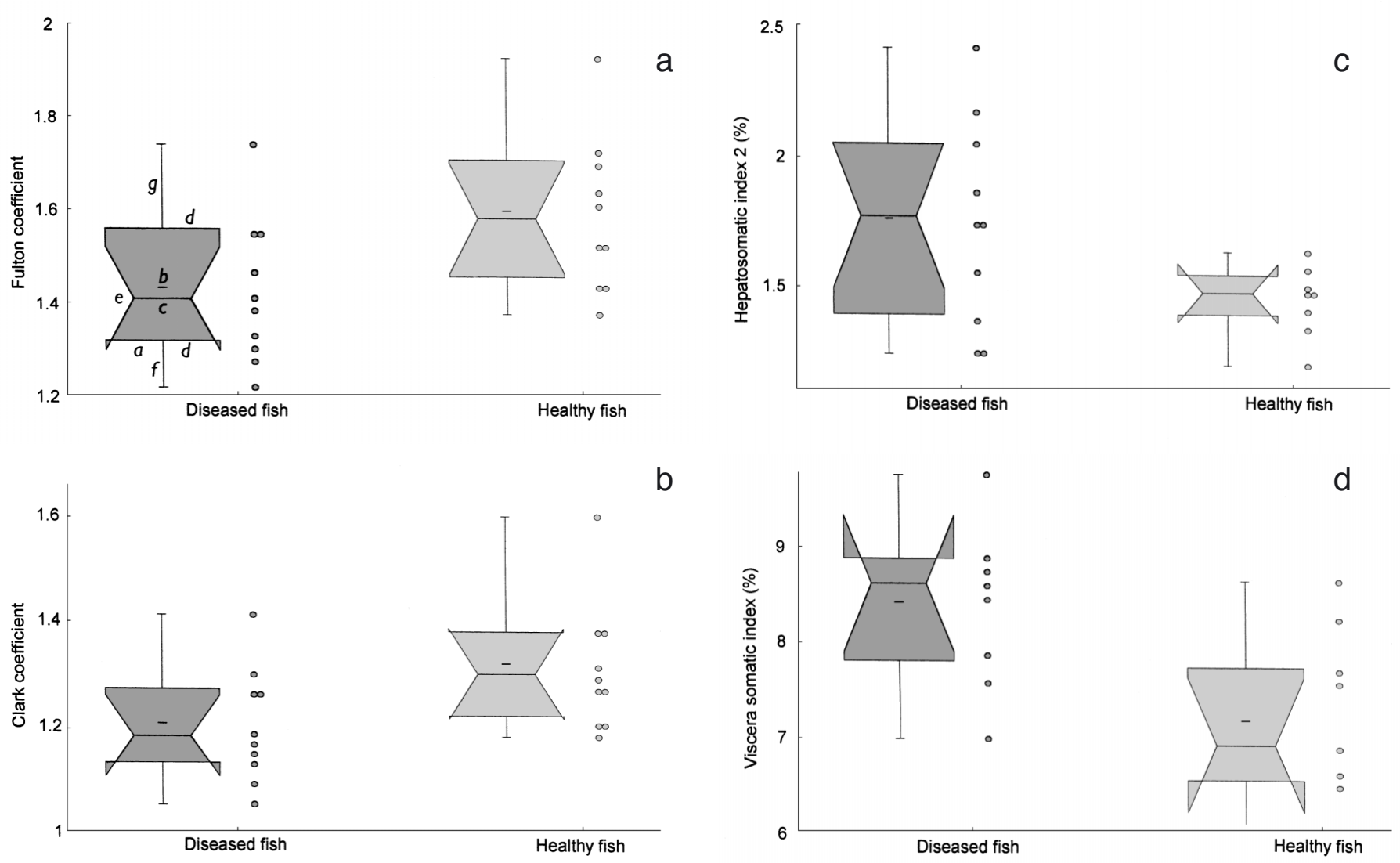

Fig. 1. Oncorhynchus mykiss. Condition indices of the diseased (viral haemorrhagic septicaemia virus; VHSV) and healthy rainbow trout represented by notch box graphs with filaments: $a=$ width of the box, indicating the size of the set; $b=$ mark inside the box, showing the position of the arithmetic mean; $c=$ mid-diagonal of the box, representing the position of the median in relation to the y-axis; $d=$ lower and upper edge of the box, indicating successively the position of the lower and upper quartiles; the outgrowths on the upper and lower edges of the box mean that the confidential interval has exceeded the value of the upper and lower quartiles; $e=$ width of the notch, corresponding to the confidence interval around the median; $f=$ the lower filament, with a length corresponding to the value of the lower quartile reduced by 1.5 times the span of the quartiles. If this value is lower than the minimum value in the set, the length of the filament corresponds to this minimum value. If values lower than those corresponding to the coordinate of the end point of the lower filament do occur in the set, then these values are signalled as remote. $g=$ The upper filament, with a length corresponding to the value of the upper quartile enlarged by 1.5 times the span of the quartiles. If this value is higher than the maximum value in the set the length of the filament corresponds to this maximum value. If values higher than those corresponding to the coordinate of the end point of the upper filament do occur in the set, then these values are signalled as remote

2.45 vs 3.15 to $3.91 ; \mathrm{Na}^{+}$: 133 to 154 vs 151 to 160$)$. The concentration of $\mathrm{K}^{+}$was increased (2.6 to 4.9 vs 1.1 to 4.8). Of the 2 aminotransferases under study, there was an increased catalytic concentration only in ALT, for which values ranged between 0.52 and 2.46 in the affected fish, whereas in the healthy fish the range was 0.39 to 1 . A substantial growth in enzyme activity was recorded in LD: it was 8 times higher in diseased fish than in healthy fish, showing a considerable fluctuation in the former (69.3 to 345.6) and greater homogeneity in the latter (13.6 to 42.4 ). The catalytic concentration of ALP was reduced several times (1.4 to 5 vs 7.9 to 20 ). The increased catalytic concentration of AST (5.14 to 8.01 vs 3.54 to 6.68 ) was an interesting finding in the diseased fish in Group A, but was absent in Group B.
Comparison of the results of the $t$-tests between the diseased and healthy fish showed that the fish in Group B gave a greater biochemical response. BUN, CREA and TGL were not determined in Group A for technical reasons: if these are excluded from the evaluation, we see a significant difference between Group $\mathrm{B}$ fish and the healthy fish in 9 cases, and between Group A fish and the healthy fish in only 3 cases.

\section{Biometry of organs}

When we compared the fish in a chronic stage of VHS with disease-free fish, we observed a significantly $(p=0.03)$ lower FC $(1.43 \pm 0.155$ vs $1.6 \pm 0.165)$ and CC 
$(1.2 \pm 0.108$ vs $1.32 \pm 0.12)$, and significantly $(\mathrm{p}=0.04$ and 0.01 , respectively) higher HI $2(1.76 \pm 0.389$ vs $1.46 \pm 0.137)$ and VSI $(8.41 \pm 0.858$ vs $7.19 \pm 0.921)$. The condition parameters are graphically shown in Fig. 1.

\section{DISCUSSION}

The occurrence of VHS in rainbow trout as described in this study is accompanied by severe changes in the blood, including, in particular, signs of anaemia, disorders in nitrogen, carbohydrate, lipid and mineral metabolism, and changes in enzyme activities.

Related to anaemia is the lethargic behaviour of the fish, resulting from poor metabolism of oxygen, combined with a reduction of the $\mathrm{Hb}$ level. This decrease was seen not only in relation to the control fish, but also in relation to the physiological values; it is particularly the case that fish in the chronic stage of the disease (Group B) have Hb levels which are far below the reference range. The hypochromic normocytic anaemia in the fish from Groups A and B can be considered to be a symptomatic secondary anaemia typical of the course of infectious diseases (Donner \& Friedmann 1977). Reduced erythropoiesis is the most distinct feature of the pathogenesis in this case. The histological finding of necrosis at the haemopoietic site of the kidney correlates with the reduced erythropoiesis. The decrease of red blood cells in the peripheral blood is not compensated by the production of new cells because of the considerable loss of haemopoietic tissue. The premature intravascular destruction of red blood cells is primarily ascribed to sepsis. Anaemia is commonly found in cases of chronic glomerulonephritis (Donner \& Friedmann 1977), and according to Erslev (1970; cited in Neuwirt et al. 1983) chronic renal failure with uraemia is regularly accompanied by anaemia, the intensity of which is in correlation with the degree of uraemia. However, no relation between $\mathrm{Ht}$ and the urea level was found in our case.

Many authors have described anaemic states in cases of bacterial infection of salmonids. Waagbø et al. (1988) described signs of severe anaemia combined with a reduction of RBCc, Ht and $\mathrm{Hb}$ in Atlantic salmon Salmo salar suffering from the 'Hitra disease', and Harbell et al. (1979) also described such signs in the coho salmon Oncorhynchus kisutch subjected to experimental infection with a virulent Vibrio anguillarum. Cardwell \& Smith (1971) found a progressive effect on the $\mathrm{Ht}$ and $\mathrm{Hb}$ in juvenile chinook salmon with vibriosis. Foda (1973) described a reduction of $\mathrm{Hb}$ in a severe Aeromonas infection in Atlantic salmon. Barham et al. (1980) recorded a reduction of $\mathrm{Hb}$ and $\mathrm{Ht}$ in rainbow trout infected with the Aeromonas and
Streptococcus bacteria. A decrease in $\mathrm{Ht}$ in a bacterial kidney disease in brook trout is also reported by Hunn (1964). The RBCc, Ht and Hb levels were significantly low in Aeromonas, which causes severe skin lesions in rainbow trout (Řehulka 2002). However, the MCV, $\mathrm{MCH}$, and $\mathrm{MCHC}$ were normal. The changes in the basic haematological indices may also be induced by some parasitic protozoa, or certain metazoan parasites. Kawatsu (1978) found that the RBCc, Hb, Ht and MCH declined as the intensity of Eudiplozoon nipponicum grew. Hoffmann \& Lommel (1984) indicate that rainbow trout affected by proliferative kidney disease (PKD) have distinct anaemia with diminished $\mathrm{Ht}, \mathrm{Hb}$ and RBCC.

A reduction of TP in salmonids with infectious disease is described by many other authors. Mulcahy (1971) studied such a decrease in the serum of the brown trout and Atlantic salmon with ulcerative dermal necrosis (UDN) and single fungal infection Saprolegnia ferax, and in salmon fingerlings with fin rot and furunculosis (Mulcahy 1969). Hypoproteinaemia was reported by Harbell et al. (1979) to occur in this salmon with vibriosis, and Hunn (1964) found it to occur in brook trout with bacterial kidney disease. Total plasma protein concentrations were significantly lower in diseased rainbow trout (Barham et al. 1980, Řehulka 2002), and so was the total serum protein in Atlantic salmon (Waagbø et al. (1988). The hypoproteinaemia, which was found in severely anaemic fish, corresponded with the histological finding in kidney and acute hepatitis: these conditions are mainly characterised by the loss of albumin and decrease in its synthesis (albumin contributes to maintaining colloidal osmotic pressure in the blood flow). Hypoalbuminaemia leads to swellings and ascites. Diminished total serum protein and an increase in blood urea in PKD-affected fish are described by Hoffmann \& Lommel (1984).

The increased level of urea is ascribed to its retention, which is due to renal insufficiency, and also to escalated protein catabolism (řehulka 2002), taking place where sepsis occurs (Racek et al. 1999). The recorded lower concentration of CREA as another nonprotein nitrogen catabolite corresponds to the values published by Waagbø et al. (1988).

Barham et al. (1980) provide evidence of the fact that an infectious disease may affect the glucose level. These authors draw attention to the lower concentration of glucose in infected rainbow trout with bacterial aetiology, as described above. However, Haider (1969) reported a VHS-induced hyperglycaemia in the course of a nephritic syndrome. Our finding of a $50 \%$ fall of the plasma glucose level only in fish suffering from a severe anaemia can be ascribed to the depletion of the reserve of liver glycogen in cases of failure of liver functions, combined with the fact that the sick fish 
show no interest in food. An increase in glucose level is described by Harbell et al. (1979), and the increase in blood glucose in infected fish is characteristic of a stress response (Black et al. 1961).

In addition to glucose, higher non-esterified fatty acids are among the most important sources of energy. The changes in lipoprotein metabolism, which manifest themselves in a marked reduction of the level of TGL, corresponded with the results published by Waagbø et al. (1988) and Řehulka (2002). Hypoglycerolaemia may be related to hepatopathy, fasting and severe septic conditions.

The significant findings also included changes in the mineral metabolism of inorganic phosphate, total calcium, sodium and potassium. Hypophosphataemia and hypercaliaemia were shared by both groups of fish. The levels of calcium and the sodium cation were reduced only in severely anaemic fish. In homeothermic vertebrates (Racek et al. 1999), hypophosphataemia may occur in cases of a tubular defect in the reverse resorption of phosphates, and also in sepsis; a decrease in calcium may correspond with losses of protein. According to (Racek et al. 1999), a decrease in plasma sodium occurs in cases of stronger hypoproteinaemia, where the anion column in the plasma grows and where an adequate decrease in the total cation concentration is needed if electric neutrality is to be retained. Such cations also include sodium, which is the main extracellular cation. Hypercaliaemia might be due to inflammatory damage to the glomerular system. Barham et al. (1980) describe a decrease in sodium.

The increase in the catalytic concentration of both aminotransferases (ALT and AST) in the diseased fish testifies an increased permeability of the cell membranes, and thereby different degrees of damage to the hepatocytes. A growth of ALT while AST remained unchanged was described by Waagbø et. al. (1988), who examined vibriosis in Atlantic salmon; Harbell et al. (1979), who studied the same disease in coho salmon, described an increased catalytic activity of AST. A significant increase in both aminotransferases was also recorded by Bell (1968) in a case of bacterial kidney disease of cultured sockeye salmon, by Racicot et al. (1975) in Aeromonas infection of rainbow trout, and by Shieh (1978) in Aeromonas salmonicida infection of brook trout. According to Jeney et al. (1990), increased ALT and AST in plasma showed tissue damage, probably due to the necrosis of haemopoietic tissues of infected wells Silurus glanis with a new serotype of Rhabdovirus carpio. A reduced catalytic concentration of ALP, as observed in this study, is also described by Waagbø et al. (1988) and Harbell et al. (1979), as distinct from the observations published by Shieh (1978). The histopathological finding in liver and the blood vessels (increased disintegration of the red blood cells) may be associated with an elevation of the catalytic concentration of LD in severely anaemic fish. An increased activity of this enzyme is also described by Harbell et al. (1979) and Racicot et al. (1975). We also consider the comparison of the red blood cell indices with a case of intraperitoneally-induced infectious haematopoietic necrosis in rainbow trout important (Amend \& Smith 1975). Similar to our findings, these authors state a reduction in the $\mathrm{RBCC}_{1} \mathrm{Ht}$ and $\mathrm{Hb}$, but they report unchanged $\mathrm{MCV}, \mathrm{MCH}$ and $\mathrm{MCHC}$ concentrations. We found, like Amend \& Smith (1975), a reduction of inorganic phosphate and total calcium. While the decrease in inorganic phosphate level occurred in both stages of the disease, the decrease in total calcium was only recorded in fish in the chronic stage of VHS. However, like Amend \& Smith (1975), we observed an unchanged level of glucose only in fish in the acute stage of disease. Fish with chronic VHS had a lower glucose level.

Comparison of the haematological and biochemical responses between Groups A and B shows the same levels in 6 cases $\left(\mathrm{RBCC}_{1} \mathrm{Ht}, \mathrm{Hb}, \mathrm{UA}, \mathrm{P}, \mathrm{K}^{+}\right)$and different levels in 11 cases (MCV, MCH, MCHC, TP, GL, Ca, $\left.\mathrm{Na}^{+}, \mathrm{ALT}, \mathrm{AST}, \mathrm{ALP}, \mathrm{LD}\right)$. It can thus be deduced that changes in metabolism and enzyme activities grow with the development of the anaemic state.

Like Waagbø et al. (1988), we recorded a higher hepatosomatic index in the diseased fish, which is also a typical sign in cases of liver lipoid degeneration (LLD) (Ostroumova 1974, Řehulka 1989, 1990). This, as well as the lower FC, is indicative of a poor body condition. The reverse was observed in bacterial infection, which causes severe skin lesions in rainbow trout (Řehulka 2002) and brook trout Salvelinus fontinalis (Řehulka 1999): sick fish had better nourishment (FC: $1.66 \pm 0.047$ and $1.51 \pm 0.082)$ than healthy fish $(1.42 \pm$ 0.039 and $1.43 \pm 0.044)$.

These results display the changes that take place in the peripheral blood of the rainbow trout affected by a severe salmonid virosis. The red blood cell was subjected to 6 haematolotical tests, and the blood plasma was subjected to 14 biochemical tests, which provided findings on changed substrate concentrations and enzyme activities. These findings will encourage efforts to extend the participation of clinical haematology and biochemistry in the screening programmes of the evaluation of the state of health of salmonids in intensive aquaculture.

Acknowledgements. This work was supported by the Grant Agency of the Czech Republic (Grant No. 525/00/0241). The author would like to thank Dr. T. Veselý of the Veterinary Research Institute in Brno, and Dr. I. Čerbáková of the State Veterinary Institute at Opava, for the virological examinations. Thanks also go to Prof. B. Minařík, PhD, of the Mendel University of Agriculture and Forestry in Brno, Department of Statistics for the graphical and mathematical processing of the results. 


\section{LITERATURE CITED}

Ahne W, Megele R, Ollenschläger B (1976) Vergleichende Infectionsversuche mit Egtvedviren (Stamm F1) bei Regenbogenforellen (Salmo gairdneri) und Goldforellen (Salmo aguabonita). Berl Muench Tieraerztl Wochenschr 89:161-164

Amend DF, Smith L (1975) Pathophysiology of infectious hematopoietic necrosis virus disease in rainbow trout (Salmo gairdneri): early changes in blood and aspects of the immune response after injection of IHN virus. J Fish Res Board Can 31:1371-1378

Amlacher E, Ude J, Rudolph C, Ernst G (1980) Direct electron microscopical visualization of the presumptive virus of viral haemorrhagic septicaemia (VHS) in the rainbow trout Salmo gairdneri Richardson and additional histopathological and haematological observations. J Fish Dis 3:55-62

Barham WT, Smit GL, Schoonbee HJ (1980) The haematological assessment of bacterial infection in rainbow trout, Salmo gairdneri Richardson. J Fish Biol 17:275-281

Bell RG (1968) Distribution of transaminases (aminotransferases) in the tissues of pacific salmon (Oncorhynchus) with emphasis on the properties and diagnostic use of glutamin-oxalacetic transaminase. J Fish Res Board Can 26(6):1247-1268

Black EC, Robertson AC, Parker RR (1961) Some aspects of carbohydrate metabolism in fish. In: Martin AW (ed) Comparative physiology of carbohydrate metabolism in heterothermic animals. University of Washington Press, Seattle, p 89-124

Cardwell RD, Smith LS (1971) Hematological manifestations of vibriosis upon juvenile chinook salmon. Prog Fish Cult 33:232-235

Deufel J (1959) Dégénérescence graisseuse et dégénérescence infectieuse chez la truite arc-en-ciel. Plaisirs de la Péche, p 220-224

Donner L, Friedmann B (1977) Haematology. Avicenum, Praha (in Czech)

Foda A (1973) Changes in hematocrit and hemoglobin in Atlantic salmon (Salmo salar) as a result of furunculosis disease. J Fish Res Board Can 30:467-468

Haider G (1969) Zur Semiologie der infektiösen VirusSeptikämie bei Regenbogenforelle. Z Fisch NF 17: 497-513

Harbell SC, Hodgins HO, Schiewe MH (1979) Studies on the pathogenesis of vibriosis in coho salmon, Oncorhynchus kisutch (Walbaum). J Fish Dis 2:391-404

Hille S (1983) Zur Wirkung von Krankheiten auf Blutbestandteile der Regenbogenforelle. I. Virale Hämorrhagische Septikämie. Fisch Umwelt H 12:29-37

Hoffmann R (1980) Untersuchungen des roten Blutbildes bei Viraler Hämorrhagischer Septikämie (VHS) der Regenbogenforellen (Salmo gairdneri). Fisch und Umwelt 8:37-48

Hoffmann R, Lommel R (1984) Haematological studies in proliferative kidney disease of rainbow trout, Salmo gairdneri Richardson. J Fish Dis 7:323-326

Hoffmann R, Pfeil-Putzien C, Dangschat H, Vogt M (1979) Untersuchungen zur Pathogenese der Viralen Hämorrhagischen Septikämie (VHS) bei Regenbogenforellen (Salmo gairdneri). Berl Muench Tieraerztl Wochenschr 92: 180-185

Hunn J (1964) Some patho-physiologic effects of bacterial kidney disease in brook trout. Proc Soc Exp Biol Med 117: 383-385

Jeney G, Jeney Z, Oláh J, Fijan N (1990) Effect of rhabdovirus infection on selected blood parameters of wels. Aquacult Hungarica (Szarvas) VI:153-160
Jensen MH (1963) Preparation of fish tissue cultures for virus research. Bull Off Int Épizoot 59:131-134

Kawatsu H (1978) Studies on the anemia of fish. IX. Hypochromic mikrocytic anemia of crucian carp caused by infestation with a Trematode, Diplozoon nipponicum. Bull Jpn Soc Sci Fish 44:1315-1319

Lehmann J, Stürenberg FJ (1975) Hämatologisch-serologische Substratuntersuchungen an der Regenbogenforelle (Salmo gairdneri Richardson). II. Beschreibung und Darstellung der wichtigsten Zellen in der Blutbildungsstatte und im peripheren Blutgefäßsystem. Gewaess Abwass 55/56:1-123

Meier W, Pfister K (1981) Viral hemorrhagic septicaemia (VHS) in pike (Esox lucius L.): clinical macroscopic, histological and electron-microscopical findings: direct visualization of the Egtved-virus. Schweiz Arch Tierheilkd 123: 37-49

Mulcahy MF (1969) Serum protein changes in UDN-infected Atlantic salmon: a possible method of diagnosis. J Fish Biol 1:333-338

Mulcahy MF (1971) Serum protein changes associated with ulcerative dermal necrosis (UDN) in the trout, Salmo trutta L. J Fish Biol 3:199-201

Neuwirt J, Nečas E, Kornalík F, Šulc K (1983) Pathophysiology of blood. Avicenum, Praha (in Czech)

Ostroumova IN (1974) Vyrashchivanie lichinok, segoletok i dvukhletok raduzhnoi foreli na sukhich granulirovanykh kormakh. Vopr Forelevodstva 97:42-53 (in Russian)

Pöllnitz CHrv, Hille S, Schröder G (1994) Hämatologische Untersuchungen an gesunden und kranken Forellen. I. Virale Hämorrhagische Septikämie (VHS). Z Angew Zool 80:69-85

Post G (1966) Serum proteins and antibody production in rainbow trout (Salmo gairdneri). J Fish Res Board Can 23: 1957-1963

Racek J, Eiselt J, Friedecký B, Holecek V and ð others (1999) Clinical biochemistry. Karolinum, Praha

Racicot JG, Gaudet M, Leray C (1975) Blood and liver enzymes in rainbow trout (Salmo gairdneri) with emphasis on their diagnostic use: study of $\mathrm{CCl}_{4}$ toxicity and case of Aeromonas infection. J Fish Biol 7:825-835

Rehulka J (1989) Determining the optimum doses of Kurasan (ethoxiquinolin) and butylhydroxytoluol (BHT) in dry pellets: effect of both anti-oxidants on some haematological and condition parameters of rainbow trout, Salmo gairdneri Richardson. Aquac Fish Manage 20:295-310

Rehulka J (1990) Effect of hydrolytically changed and oxidized fat in dry pellets on the health of rainbow trout, Oncorhynchus mykiss (Walbaum). Aquac Fish Manage 21:419-434

Rehulka J (1999) Changes in the blood of the brook trout, Salvelinus fontinalis (Mitchill,1815) affected by infectious skin lesions. 9th Int Conf Diseases of Fish and Shellfish, Rhodes, 19 to 24 September 1999. Book of abstracts, EAFP (European Association of Fish Pathologists), Rhodes

Rehulka J (2002) Aeromonas causes severe skin lesions in rainbow trout (Oncorhynchus mykiss): clinical pathology, haematology and biochemistry. Acta Vet Brno 71:351-360

Řehulka J, Minařík B (2003) Normal ranges for red blood cell indices of rainbow trout, Oncorhynchus mykiss (Walbaum) in aquaculture in the Czech Republic. Aquacult Res (in press)

Reichenbach-Klinke HH (1970) Blutbild Zuckergehalt und Enzymspiegel bei VHS, Muench Beitr Abwass FischFlussbiol 18:83-90

Schlotfeld HJ, Ahne W, Vestergård-Jørgensen PE, Glende W (1991) Occurrence of viral haemorrhagic septicaemia in 
turbot (Scophthalmus maximus) — a natural outbreak. Bull Eur Assoc Fish Pathol 11:105-107

Shieh HS (1978) Changes of blood enzymes in brook trout induced by infection with Aeromonas salmonicida. J Fish Biol 12:13-18

UNISTAT $^{\circledR}$ (1995) Version 4 for MS Windows ${ }^{\mathrm{TM}}$. Unistat, London

Editorial responsibility: Jo-Ann Leong,

Kaneohe, Hawaii, USA
Waagbø R, Sandnes K, Espelid S, Lie O (1988) Haematological and biochemical analyses of Atlantic salmon, Salmo salar L., suffering from coldwater vibriosis ('Hitra disease'). J Fish Dis 11:417-423

Zwillenberg LO, Jensen MH, Zwillenberg HHL (1965) Electron microscopy of the virus of viral haemorrhagic septicaemia of rainbow trout (Egtved virus). Arch Virusforsch 17:1-19

Submitted: March 8, 2002; Accepted: June 12, 2002

Proofs received from author(s): August 18, 2003 